University of Miami Law School Institutional Repository

University of Miami Inter-American Law Review

2-1-1977

\title{
The Inter-American Convention on International Commercial Arbitration
}

Follow this and additional works at: http://repository.law.miami.edu/umialr

\section{Recommended Citation}

The Inter-American Convention on International Commercial Arbitration, 9 U. Miami Inter-Am. L. Rev. 43 (1977) Available at: http://repository.law.miami.edu/umialr/vol9/iss1/3

This Article is brought to you for free and open access by Institutional Repository. It has been accepted for inclusion in University of Miami InterAmerican Law Review by an authorized administrator of Institutional Repository. For more information, please contact library@law.miami.edu. 


\section{THE INTER-AMERICAN CONVENTION ON INTERNATIONAL COMMERCIAL ARBITRATION*}

\section{INTRODUCTORY Note}

On 30 January, 1975, a landmark development in commercial arbitration in the Western Hemisphere occurred with the adoption of the InterAmerican Convention on International Commercial Arbitration by the Inter-American Specialized Conference on Private International Law held in Panama City.' Since the adoption of the Converition on 30 January, 1975, it has been signed by thirteen ${ }^{2}$ of the twenty member countries of the Organization of American States (OAS) and ratified by $\mathrm{two}^{3}$ of the member countries.

Although the United States actively participated in the drafting of the Convention, in conformity with traditional practice, the United States refrained from signing or ratifying the document (see Appendix) until interested organizations could review and comment on it. ${ }^{4}$ This article is the result of a review by the Committee on Arbitration of the Association of the Bar of the City of New York completed on 7 May 1976, which recommended that the United States sign and ratify the Convention, and make it effective in the United States through the Federal Arbitration Act. However, the United States has not signed or ratified the Convention.

\section{Summary of the Convention}

The immediate antecedents of the Convention were the Draft Uniform Law on Commercial Arbitration approved by the Third Meeting of the Inter-American Council of Jurists held in Mexico in $1956,{ }^{5}$ which recommended adoption of the Draft Law by states members of the OAS; the Draft Convention on International Commercial Arbitration proposed by the Inter-American Juridical Committee in Rio de Janeiro in $1967 ; 6$ and of

*This article is being reprinted with the permission of Robert A. Koch, Chairman of the Committee on Arbitration of the Association of the Bar of the City of New York. The Committee has acknowledged the contribution of its member, Frank $E$. Nattier, and the cooperation of René Hollyer, Thomas J. Skola, Frederick K. Howard, and Eric Bergsten in the preparation of this report. 
course the United Nations Convention on the Recognition and Enforcement of Foreign Arbitral Awards, signed in New York on 10 June 1958.

Articles 1 through 3 relate to the initiation and conduct of arbitral proceedings. They rest on the basic legal premise that the provisions of a treaty supersede conflicting provisions of municipal law. ${ }^{8}$

Article 1 establishes at the outset that an agreement to submit future or existing disputes in a commercial transaction to settlement by arbitration is valid; and that the agreement can be contained in an instrument signed by the parties, or in an exchange of letters, telegrams or telex communications. This Article was designed to help cut through a number of formal. istic problems arising out of the domestic laws of several countries, on which agreements to arbitrate had foundered in the past. ${ }^{9}$

Article 2 says that arbitrators shall be appointed in the manner agreed by the parties, who may delegate the appointment to a third party which may be either a natural or a juridical person. Arbitrators may be nationals or foreigners. These provisions, too, aim to overcome obstructive restrictions in the laws of several countries. They provide for participation of non. governmental arbitration agencies such as the Inter-American Commercial Arbitration Commission, the American Arbitration Association and others.

Article 3 stipulates that unless the parties agree otherwise an arbitration shall be conducted under the rules of procedure of the Inter.American Commercial Arbitration Commission (IACAC). ${ }^{10}$ This Article has been especially applauded as promoting procedural uniformity in the Hemisphere and as overcoming the uncertainties arising out of the insistence by some countries that local procedural rules (sometimes difficult to ascertain) govern arbitrations. ${ }^{11}$

Article 4 provides that an arbitral award which is no longer appeal. able under the applicable law or procedural rules shall have the force of a final judicial judgment. Its execution or recognition may be ordered or be demanded (podra exigirse, in the Spanish text) in the same manner as that of decisions handed down by national or foreign ordinary courts, in accordance with the procedural laws of the country where it is to be executed and the provisions of international treaties. Article 4 applies to the execution of an arbitral award in the country in which it was made, as well as to the execution or recognition of an award given in another ratifying or adhering country; and in either case the Convention might supersede existing domestic law. 
Article 5, specifying the grounds on which a court of one Convention country may refuse to recognize an arbitral award given in another, is almost a replica of the corresponding article of the U.N. Convention. The Article consists of two parts. The first provides that refusal is authorized only if the party opposing execution can prove that the award was tainted with one of five specified deficiencies. The second part authorizes refusal if the subject of the dispute cannot be settled by arbitration under the law of the country of execution, or if execution would be contrary to the public policy of that country. In no case is refusal authorized by allegations that the arbitrator(s) committed errors of law or of fact.

Article 6 provides for the case in which a party opposing execution of an award alleges that it is not yet binding on the parties, or has been annulled or suspended by a competent authority of the country in which the award was made. In that event, the authority to which application for enforcement is made may postpone decision, and at the request of the petitioner may require the opposing party to "provide appropriate guarantecs." This Article is taken verbatim from the U.N. Convention.

Articles 7, 8 and 9 say that the Convention is open for signature by all States members of the Organization of American States, and for accession by any other State. Instruments of ratification and accession are to be deposited with the General Secretariat of the OAS.

Under Article 10 the Convention will enter into force thirty days after deposit of the second instrument of ratification; and for each ratify. ing or acceding State thereafter, thirty days after deposit of the respective instrument.

Article 11, the "federal clause," is designed to facilitate signature or accession by countries such as the United States, Argentina, Mexico and Canada. If a country has two or more territorial units in which different systems of law apply in relation to matters dealt with in the Convention it may at the time of signature, ratification or accession declare that the Convention shall apply to all the units or only to some of them; and it may modify that declaration subsequently.

Article 12 provides that the Convention shall remain in effect indefinitely, but any State may denounce it, effective one year after the General Secretariat of the OAS receives notification. It will remain in effect, however, for the other parties. 


\section{The Background in Latin America}

Until 1975, the countries of Latin America had been generally unreceptive towards efforts to achieve uniformity and greater effectiveness in international commercial arbitration procedures. It may be useful to look at some of the factors which lay behind this attitude.

Provisions regarding commercial arbitration are contained mainly in the Codes of Procedure of the several countries and in the Commercial Codes, which were influenced by Iberian, French and other European laws; ${ }^{12}$ and in some cases in their Constitutions. ${ }^{13}$ While all recognize arbitration in principle, all (with a few recent exceptions) contain provisions which limit its availability and effectiveness. Some of these impediments apply to both domestic and international arbitrations; others affect enforcement of awards made abroad. Many continue to this day.

Perhaps the most general and serious obstacle is that, with the exception of Ecuador ${ }^{14}$ Chile $^{15}$ and Bolivia, ${ }^{16}$ few if any of these laws provide for direct enforcement of agreements to settle future disputes by arbitration. ${ }^{17}$ Most of the countries require that when a dispute arises the agreement to arbitrate (clausula compromisoria) must be perfected by preparing an agreement of submission (compromiso), in which the matters in dispute are described, arbitrators are appointed and other aspects of the proceeding agreed. In a few countries, nevertheless, the court upon application of a party will require the other to sign a submission agreement and if he refuses, will itself write the submission, ${ }^{18}$ either pursuant to a specific provision of law, ${ }^{19}$ by judicial discretion ${ }^{20}$ or by interpretation of a provision which permits judicial assistance by appointing arbitrators. ${ }^{21}$

In some cases, the submission agreement must be set forth in a formal notarial document (escritura priblica). A submission agreement will be enforced by the court in a summary proceeding, in many countries. ${ }^{22}$ The requirement of a submission agreement raises questions in a particular case as to whether a respondent can revoke the agreement to arbitrate before the submission agreement is signed; $;^{23}$ or simply refuse to appoint his arbitra. tor (if that is what the arbitration clause calls for) or otherwise to participate in the arbitration; or perhaps bring an ordinary action in court on a matter covered by the agreement to arbitrate, which, because ordinary actions normally take a long time, might have the effect of delaying a decision for several years.

The procedural laws of the following thirteen countries provide, in varying ways, for assistance by the courts to prevent the refusal of one of 
the parties to cooperate from disrupting the arbitral process:24 Argentina, Bolivia, Colombia, Costa Rica, Chile, Ecuador, El Salvador, Guatemala, Mexico, Nicaragua, Panama, Peru, and Uruguay. Unless, however, the law provides for summary procedure, the claimant would have to bring an ordinary action in court, which would be likely to involve both expense and delay. ${ }^{25}$

In only a few countries do the courts stay a court action brought on a dispute covered by an arbitration clause, ${ }^{26}$ except after a submission agreement has been signed.27 In most of the countries, notice of the initiation of arbitration, appointment of arbitrators and related matters is subject to the same formal requirements of personal notification (e.g., service by a court official) as are notices in litigation. ${ }^{28}$ In Argentina and Colombia, arbitrators must be local nationals or residents, and in some countries must be lawyers. ${ }^{29}$

Another serious obstacle is the failure of the laws of most of the countries to limit appeals from or judicial review of arbitral awards. ${ }^{30}$ Related to this problem is the requirement in some countries that a judicial order of confirmation, or exequatur, be obtained in order to enforce an award. ${ }^{31}$

Although the need is universally recognized for a right to appeal from an award in cases of fraud, gross partiality on the part of the arbitrators, and when the terms of the referral to arbitration have been exceeded, when appeals can be taken on grounds so broad as virtually to permit re-litigation of the merits of the dispute, arbitration not only is uncertain, but may become a pointless and expensive exercise. The Mexican amparo, a constitutional procedure permitting a review by the Supreme Court or other federal appellate court of alleged violations by a governmental authority of individual rights, which potentially is available to the losing party in every arbitration and permits review of every aspect of the arbitral proceeding, presents special difficulties in this regard. ${ }^{32}$

The obstacles just discussed can relate to both domestic and international arbitration. Other provisions can raise problems for the enforcement of an award given in another country. Again, there are wide disparities among the laws of the several countries of Latin America.

Several (like the United States, until 1970) have no statutory rules relating specifically to foreign arbitral awards, ${ }^{33}$ which are treated substantially in the same way as are foreign judgments. Among the various requirements for recognition and enforcement are: That the award was 
given in a proceeding in which personal jurisdiction over the defendant was obtained; that it constitutes a final and binding determination of the dispute under the laws of the place of arbitration; and that execution will not be contrary to the laws or public policy of the place where enforcement is sought. Most require some form of authentication of the award, which in practice usually means reducing it to a judgment in the country where it was given. Also general is a requirement of reciprocity; i.e., a showing that the country of the award will enforce awards given in the country where enforcement is sought. ${ }^{34}$ Argentina reportedly will enforce awards which meet the other requirements, without regard to reciprocity. ${ }^{35}$ The burden of proof is on the party seeking enforcement, and the extent of review of the arbitral proceeding is potentially broad.

These differences among the substantive laws on arbitration, and in the complex rules on conflicts of laws, inevitably have given rise to confusion and uncertainty, and have afforded abundant opportunities for ob. struction and delay. ${ }^{36}$ The result was to undermine the confidence of lawyers and the business community in the arbitral process as an alternative to the no less unsatisfactory prospect of relying on the slow, uncertain and costly procedures of litigation. Lack of adequate means of settling disputes imposed and still imposes heavy restraints on the needed development and growth of international commerce.

The nations of the Western Hemisphere were among the first to seek through multilateral agreement some uniformity in the rules governing recognition of foreign judgments and arbitral awards. ${ }^{37}$ The 1889 Montevideo Treaty on International Procedural Law provides for recognition of judgments and arbitral awards from other Contracting States. While it was modest in its ambitions, it was ratified only by Argentina, Bolivia, Colombia, Paraguay, Peru and Uruguay. ${ }^{38}$

Establishment of a system of arbitration courts for the settlement of commercial disputes was recommended by the First Pan American Financial Conference, held in Washington in 1915, and the Fifth International Conference of American States in 1923 adopted a recommendation calling upon the Chambers of Commerce of the principal commercial centers to come to an agreement for the extrajudicial arbitration of commercial controversies. ${ }^{39}$

The first multilateral treaty dealing specifically with commercial arbitration was the Protocol on Arbitration Clauses, drafted in Geneva in 1923 (the "Geneva Protocol"). It was signed by several Latin American 
countries, but ratified only by Brazil. ${ }^{40}$ Shortly thereafter, in 1927, the Convention on the Execution of Foreign Arbitral Awards was signed, also in Geneva (the "Geneva Convention"), but it was not ratified by any Latin American country. ${ }^{41}$

The Inter-American Conference on Private International Law, held in Havana in 1928, approved the ambitious Code of Private International Law based on the draft of the great Cuban jurist, Antonio de Bustamante, which includes provisions on the recognition and enforcement of foreign arbitral awards, as well as of foreign judgments (Article 423). The Convention adopting the Code was ratified by fifteen Latin American countries (not including Argentina, Colombia, Mexico, Paraguay or Uruguay), but by many with crippling reservations. ${ }^{42}$

In 1933, the Pan American Union, with the collaboration of the American Arbitration Association, submitted a report to the Seventh American International Conference, held in Montevideo, recommending preliminary steps to create a regional arbitration system for the American continent. The Conference adopted a resolution proposing that, "to strengthen relations among the Chambers of Commerce of the Americas," an Inter-American Commercial Agency be created, completely independent of official control, to assume responsibility for establishing an inter-American system of arbitration. ${ }^{43}$ The Inter-American Commercial Arbitration Commission was set up in 1934 pursuant to this resolution, which may prove to have been one of the most fruitful initiatives in the field of inter. American commercial arbitration.

In the same resolution, the Conference called upon each country to adopt several basic standards in matters of procedure, which it described as essential to the successful functioning of an American arbitration system, among them these: ${ }^{44}$

a) Agreements to arbitrate, whether relating to existing or future controversies, should be valid and enforceable; and where enforcement is not provided for by law, trade discipline should be provided.

* * *

g) Waiver of the right to appeal should be provided for in the rules, which should be binding on the parties, and should limit the grounds for appeal to procedural matters and to such questions of law as both parties agree to submit to the court.

Colombia incorporated all the recommended standards into a modern arbitration law adopted in $1938 ;^{+5}$ since then, however, a new Code of 
Civil Procedure, effective 1 January 1971, has superseded the law in many respects, especially by widening the grounds for appeal. ${ }^{46}$ Brazil adopted some of the recommendations in 1939 , but did not recognize the validity of agreements to submit future disputes to arbitration $;{ }^{47}$ and the new Brazilian Code of Civil Procedure, effective 1 January 1974, still does not provide for the enforceability of such agreements. ${ }^{+3}$ Ecuador followed Colombia's lead in 1963.49

In 1940, seven Latin American states ${ }^{50}$ signed a second Treaty of International Procedural Law in Montevideo, which was designed to update the 1889 agreement and to simplify procedures for carrying out foreign judgments and arbitral awards issued in the signatory states. ${ }^{51}$ Only Argentina, Paraguay and Uruguay ratified it, and it is still in effect for them. ${ }^{22}$

After several years of little movement, having seen that the method of multilateral agreements had produced few practical advances, the InterAmerican Council of Jurists in 1954 prepared a Draft Uniform Law on Commercial Arbitration, hased on the standards of the Montevideo resolution of 1933, the Rules published by the Inter-American Commercial Arbitration Commission and the Colombian Law of $1.938 . .^{53}$ After extensive study and debate, and minor modifications, the Council approved the Draft Uniform Law in 1956 and recommended that the American Republics adopt it in accordance with their constitutional procedures "in such form as may be considered desirable within their several jurisdictions." 54 The draft law contained the four elements regarded as fundamental to a mod. ern, effective arbitration law: Validity of an agreement to submit future disputes to arbitration (Article 1); stay of an action brought before a court in violation of an arbitration agreement (Article 4); judicial assistance in appointing arbitrators (Article 11); and limited appeal to the courts (Article 19).

Ecuador probably was influenced by the Draft Uniform Law in adopting its new arbitration law in 1963.55 For reasons which have been variously speculated upon, no other American country has acted upon it. ${ }^{56}$

At about the same time, in April, 1954, the United Nations Economic and Social Council set up a special committee to study the recognition of foreign arbitral awards, and submit, "if it seems fit," a draft convention. The committee prepared a draft, based on one which had been drawn up by the International Chamber of Commerce to supersede the inadequate Geneva Convention. ${ }^{57}$ The Council considered the committee's report and 
draft in May, 1955, and a year later, after circulating the draft to governments and obtaining comments, called a Conference on International Commercial Arbitration, which was held from 20 May to 10 June 1958 at the U.N. Headquarters in New York. ${ }^{58}$ The Conference on 10 June approved the Convention on the Recognition and Enforcement of Foreign Arbitral Awards. ${ }^{59}$ In the Final Act, the Conference suggested several additional measures "which would contribute to increasing the effectiveness of arbitration in the settlement of private law disputes," and, inter alia, specifically recognized the work done earlier by the Inter-American Council of Jurists.

Argentina, Costa Rica, Ecuador and El Salvador signed the U.N. Convention, ${ }^{60}$ but by 1967 only Ecuador had ratified it and Trinidad and Tobago bad acceded. ${ }^{61}$

Meanwhile, a quite different kind of arbitration proposal was emerging directed primarily at the protection of private foreign investment, including a suggested German "International Convention for the Mutual Protection of Private Property Rights in Foreign Countries", in 195762 and an OECD Draft Convention on the Protection of Foreign Property in 1962.63 Under the auspices of the International Bank for Reconstruction and Development (the World Bank) the Convention on the Settlement of Investment Disputes between States and Nationals of Other States was signed in Washington in $1965^{6+}$ creating an International Center for the Settlement of Investment Disputes, utilizing arbitration procedures (the "ICSID Convention") ${ }^{65}$ This was a specialized kind of arbitration, which cannot be viewed in the same light as general commercial arbitration.

Because the ICSID Convention touches directly upon questions of control of national resources and foreign investments, which are seen as sensitive issues by the Latin American countries, ${ }^{66}$ none signed it. Only Jamaica, Guyana and Trinidad and Tobago, among the developing coun. tries of the Western Hemisphere are parties. ${ }^{67}$

The passive resistance evidenced by abstention from the ICSID Convention took a more active form in Colombia, Ecuador, Peru, Bolivia and Chile with the adoption by the Commission of the Cartagena Agreement (the "Andean Commission") of the now famous Decision 24, known as the Andean Foreign Investment Code, on 31 December 1970.68 Article 51 of the Code provides:

"No instrument relating to investments or transfers of technology may contain any provision which would remove potential conflicts or 
controversies from the national jurisdiction and competence of the receiving country or which would permit a State to be subrogated to the rights and causes of action of its nationals who are investors."

Argentina has adopted a similar rule regarding foreign investments. 69

Article 51 and the Argentine law, which have been interpreted as forbidding, in a contract of the types mentioned, any provision calling for arbitration outside the receiving country, ${ }^{70}$ are cause for serious concern to investors and licensors of technology to the Andean Group countries and to Argentina. They do not, however, repudiate or affect agreements for intemational commercial arbitration in transactions other than investments or transfers of technology. ${ }^{71}$

The Inter-American Juridical Committee returned to the fray at its 1967 session in Rio de Janeiro, faced with an excellent inter-American model arbitration law which no country had adopted and the U.N. Convention which only two members of the OAS had ratified or acceded to. Its move was to prepare a report on a Draft Inter-American Convention on International Commercial Arbitration, which would recognize the validity of the arbitration clause both for existing and for future dispules; recognize that arbitrators could be appointed by a third party; provide that the Rules of the Inter-American Commercial Arbitration Commission could govern an arbitration under certain circumstances; give the arbitration award the force of a final judgment; and limit the right of appeal to a few recognized grounds. ${ }^{72}$

The Draft Convention was forwarded, with other materials, by the Organization of American States to its member states as background for an Inter-American Specialized Conference on Private International Law, which was to be called pursuant to a resolution of 23 April 1971.73

The Conference was convened in Panama in January, 1975, and on 30 January approved the Inter-American Convention on International Commercial Arbitration, combining elements of the Inter-American Juridical Committee's 1967 Draft Convention and the U.N. Convention.

The Inter-American Bar Association, which for many years has supported the development of commercial arbitration in the Hemisphere, discussed the Inter-American Convention in depth at its XIX Conference, held in Cartagena, Colombia, 27 September-3 October 1975. After noting

"That the Convention establishes the framework for an effective and uniform system of international commercial arbitration in the 
Western Hemisphere facilitating the prompt, efficient and inexpensive settlement of international commercial disputes and

"That it is most desirable that all the American countries sign and ratify the Convention,"

the Conference adopted the following resolution: ${ }^{74}$

"To request the bar associations of the American countries and the individual members of the Inter-American Bar Association to urge their respective governments to sign, if they have not already done so, and ratify the Convention."

It can be asked, Why an Inter-American Convention? Why could not the Latin American countries simply ratify or accede to the U.N. Convention? A number of answers have been suggested. One is the common bond and facility of the Iberian languages spoken in most of the countries of the Hemisphere, and of traditions, despite differences, which they share. The Hemisphere countries including the United States, have a long history of collaboration in the Organization of American States which, while far from perfect, is the longest-lived international organization in the world. There is, in short, some kind of "family" feeling among the American countries, which may be of importance in dealing with a subject which poses as many difficulties as international commercial arbitration obviously has posed for so long. The dedicated work of the InterAmerican Commercial Arbitration Commission, especially during the past eight years, is certainly a factor. Finally, it may not be a negligible consideration that the American nations have an enormous investment of time, effort, intellect and emotion over the years in the attempt to find a Hemisphere solution to the vexing problem of devising a better method of resolving commercial disputes, and may feel that they now have an opportunity to bring that investment to fruition.

\section{The Background in the United States}

Not unlike Latin America, the United States also was slow to em. brace arbitration, either domestic or international, and even more reluctant to support efforts to achieve greater international uniformity of arbitration law and practice. ${ }^{75}$ As recently as 1915, a Federal court in New York held an agreement to arbitrate future disputes was revocable, ${ }^{76}$ and the same rule obtains in a number of states even now. 
The New York State Arbitration Law of $1920^{77}$ was the first modern arbitration law in the country. To date about thirty-five states have adopted similar laws. ${ }^{78}$ Active support by the American Bar Association, the New York State Bar Association and the Chamber of Commerce of the United States, among others, led to enactment of a Federal arbitration law in 1925.79

In 1916 and thereafter, the United States Chamber of Commerce concluded arbitration agreements with counterpart organizations in Argentina, Brazil, Colombia, Ecuador, Paraguay, Uruguay and Venezuela, ${ }^{80}$ which of course lacked the force of law and left few "footprints in the sands of time."

A modern draft of a uniform state statute was proposed in 1922, but the version finally approved by the American Bar Association in 1924. was limited to existing disputes. ${ }^{81}$

Efforts to achieve progress by treaty were no more successful. There was virtually no support in the Government for ratification of the Geneva Protocol on Arbitration Clauses of 1923 or of the Geneva Convention on Execution of Foreign Arbitral Awards of $1927 .{ }^{82}$

The Bustamante Code of $1928^{83}$ and the Treaties of Montevideo on International Procedural Law of 1889 and $1940^{84}$ (in all of which references to arbitral awards were intertwined with provisions on execution of foreign judgments) were dismissed almost summarily as dealing with a field which is "guarded most jealously" by the states. 85

Meanwhile, however, the courts were developing a decidedly liberal approach to international arbitration. The leading case in New York, Gilbert v. Burnstine, 225 N.Y. 348, 174 N.E. 706, was decided in 1931. An arbitral award given ex parte in England was enforced against a New York party, on the principle that the validity of an award depends on compliance with the law of the place of the award. ${ }^{86}$

In subsequent decisions, another ex parte English arbitral award was enforced against a New York party, ${ }^{87}$ and a Federal court in Oklahoma enforced an award given ex parte in Norway under the Rules of Conciliation and Arbitration of the International Chamber of Commerce. ${ }^{88}$

One writer has observed, "The Gilbert case and subsequent cases which followed it have probably done more within the United States for 
the enforcement of arbitration awards rendered by foreign arbitration tribunals than the Geneva Convention of 1927 did for the countries which ratified it." 89

By 1960 a Reporter's note to the Restatement of the Law of Conflict of Laws could say:90

"Foreign arbitration awards have been enforced almost invariably in the United States provided that (1) they were enforceable in the state of their rendition, (2) the cause of action on which they were based was not contrary to the strong public policy of the forum and (3) either defendant or his property was subject to the judicial jurisdiction of the arbitration tribunal and the defendant was given reasonable notice of the proceeding and a reasonable opportunity to be heard."

Since private international commerce can best flourish, however, in the atmosphere of certainty and predictability created by binding international agreements, dependence upon the policy of the forum should, at best, constitute but a secondary guarantee that valid legal contract obligations will be respected. ${ }^{91}$

In 1933, the United States initiated and promoted a resolution which was adopted by the Seventh International Conference of American States, ${ }^{92}$ calling for the creation of an Inter-American system of arbitration through the conclusion of arbitration arrangements among private trade organizations, ${ }^{93}$ probably based on the earlier efforts of the United States Chamber of Commerce mentioned above. While this resolution produced little immediate expansion in the acceptance and use of arbitration, it did, as noted above, ${ }^{94}$ lead to the organization in 1934 of the Inter-American Arbitration Commission. The Commission, despite ups and downs, has been an effective force in recent years in promoting interest in and acceptance of arbitration in the Americas.

The next development in United States policy followed the prodding of the American Arbitration Association, ${ }^{95}$ which in 1943 and 1944 proposed the inclusion of commercial arbitration provisions in trade agreements and treaties of friendship, commerce and navigation ("FCN treaties"). Such a provision was included in the treaty signed with China in 1946.96 Since then, gradually expanding the arbitration clause, ${ }^{97}$ the United States has signed FCN treaties with more than twenty countries, of 
which only Colombia, ${ }^{98} \mathrm{Haiti}^{99}$ and Nicaragua ${ }^{100}$ are in the Western Hemisphere, and of these three only the treaty with Nicaragua has become effective.

A recent example of the clause is Article 3(6) of the Treaty of Friendship, Establishment and Navigation with Belgium of 21 February $1961: 101$

"Contracts entered into between nationals and companies of either Party and nationals and companies of the other Party, that provide for settlement by arbitration of controversies, shall not be deemed unenforceable within the territories of such other Party merely on the grounds that the place designated for the arbitration proceed. ings is outside such territories or that the nationality of one or more of the arbitrators is not that of such other party. No award duly rendered pursuant to any such contract, and final and enforceable under the laws of the place where rendered, shall be deemed invalid and denied effective means of enforcement by the authorities of either Party merely on the grounds that the place where such award was rendered is outside the territories of such Party or that the nationality of one or more of the arbitrators is not that of such Party."

Although they are modest and incomplete in scope, the FCN treaty provisions do promote the usefulness of arbitration on a bilateral basis. Until 1970, provisions for enforcement of United States awards abroad existed only in those countries with which modern FCN treaties had been concluded. ${ }^{102}$

Following the abortive efforts of the early 1920's ${ }^{103}$ the Commission. ers on Uniform State Laws in 1956 promulgated an amended "Act Relating to Arbitration and to Make Uniform the . Law with Reference Thereto," 104 which has been adopted by a number of states. ${ }^{105}$

The United Nations Conference on International Commercial Arbitration, convened in New York in 1958 with the participation of forty-five countries plus observers representing most of the world's most influential organizations in the field, ${ }^{106}$ was undoubtedly the most important effort ever mounted on behalf of international commercial arbitration. Culminating several years of preparatory work, the Conference adopted the Convention on Recognition and Enforcement of Foreign Arbitral Awards of $1958,{ }^{107}$ which entered into force on 7 June $1959 .{ }^{108}$

Still the United States Government held aloof, on the well-worn ground of avoiding infringement of the jurisdiction of the states, and on 
others, ${ }^{109}$ despite repeated demonstrations by eminent legal organizations and writers that this objection could be overcome by constitutional pro. cedures. ${ }^{110}$

While action by the United States on the United Nations Convention was stalemated, a different but related development appeared in the sponsorship by the International Bank for Reconstruction and Development (the World Bank) of a new Convention on the Settlement of Investment Disputes between States and Nationals of Other States (the ICSID Convention). ${ }^{111}$ This Convention is addressed to a more specialized kind of arbitration. It is concerned with disputes between private investors on the one hand and governments on the other, and only with disputes related to international investments, rather than with general commercial arbitration. ${ }^{112}$ The United States signed the Convention in 1965 and ratified it with comparative alacrity.

The great leap forward came when the Senate gave its consent on 4. October $1968^{113}$ to ratification of the United Nations Convention, with two reservations, and Congress implemented it on 31 July 1970 by amend. ing the Federal Arbitration Act. ${ }^{114}$ The United States' instrument of ratification was deposited with the Secretary General on 30 September 1970,115 and the Convention entered into effect for the United States on 29 December 1970.

Under this method of implementation the Convention does not, as the Federal Arbitration Act does not, supersede the arbitration regimes of the several states, except for the kinds of disputes covered by the Convention. The statute provides expressly that an action or proceeding falling under the Convention shall be "deemed to arise under the laws and treaties of the United States," and the Federal district courts are given original jurisdiction regardless of the amount in controversy. ${ }^{116}$

By this relatively simple means, the Federal Government's scruple of decades about encroaching on the jurisdiction of the states was overcome, and the United States joined the world of international commercial arbitration. ${ }^{117}$

Since that time the United States Supreme Court, in Scherk v. Alberto Culver Co., ${ }^{118}$ and other United States courts ${ }^{119}$ have considered and generally enforced foreign arbitral awards under the United Nations Convention.

The United States participated actively in Panama in the debates on and drafting of the new Inter-American Convention, even though it did 
not sign the Convention. It took the position that the United States Government wants to refer the Convention to interested organizations and institutions for comment before deciding whether to sign and ratify the Convention.

\section{Questions Regarding the Convention}

Questions have been raised as to how effective in practice, for ratifying countries, the Inter-American Convention can be expected to be in facilitating the availability of arbitration, promoting the conduct of arbitration proceedings in member countries and advancing the enforceability in one member country of awards given in another.

A. Will the Convention help in breaking down obstacles to arbitration which exist now under the laws of many countries of the Western Hemisphere?

Article 4 provides:

"An arbitral decision or award that is not appealable under the applicable law or procedural rules shall have the force of a final judicial judgment. Its execution or recognition may be ordered [or demanded] in the same manner as that of decisions handed down by national or foreign ordinary courts, in accordance with the procedural laws of the country where it is to be executed and the provisions of international treaties."

This article presupposes an arbitration proceeding and an award thereunder, which award has become final under the applicable law or procedural rules. Under the present laws of a number of countries, there are several obstacles to be overcome before a claimant, whether national or foreign, can reach that position, as has been noted above. ${ }^{120}$

In every country of the Hemisphere, including the United States, local laws contain at least some of the potential obstacles to a speedy and certain arbitration. ${ }^{121}$ Any of them can be the basis of proceedings which can have the effect of delaying or defeating an arbitration, or of frustrating enforcement of an award. Many of those obstacles were erected for the purpose of protecting parties against improper or unjust awards. Like all such protective measures, they can be and are abused.

An initial question is whether arbitration is more or less subject to such abuses than ordinary litigation. While firm answers are hard to come 
by, observation seems to suggest, at least, that in most cases the obstacles and delays are no greater in arbitration and often are substantially less, ${ }^{122}$ unless local law permits the dispute to be re-litigated after an arbitral award, or the award to be reviewed broadly on appeal to a court.

The Inter-American Convention, like the U.N. document, is not directed primarily at re-shaping the local laws on arbitration, though it is expected to have some useful effects in that area. An example is Article 1. An agreement to arbitrate future disputes relating to a commercial transaction is to be recognized as valid. If it specifies the place of arbitration and adopts rules which provide for the initiation and conduct of the proceeding and the appointment of arbitrators, those provisions will be valid. While the preamble of the Convention describes it as a "convention on international arbitration" it is not clear from the language of Articles 1 through 4 whether they apply to domestic arbitration proceedings as well. It is also not clear from the language of Article 1 whether the need for a separate submission agreement in countries whose laws require it, will be obviated. Technical questions about the required form of the agreement are alleviated. Article 2 will overcome local restrictions on how arbitrators may be appointed, and nationality requirements. Article 3 not only permits adoption of the rules of the Inter-American Commercial Arbitration Commission, but makes them applicable to all arbitrations unless the parties make another provision in their agreement. Under Article 4 an arbitral award, once it is no longer appealable under the applicable law or procedural rules, will have the force of a final judicial judgment, and may be executed as such. This can avoid the requirement of some countries that a domestic award must be confirmed by a court before it can be executed.

While the Convention thus will overcome some local law obstacles in countries which ratify it, assuredly it will not overcome them all. That is not its purpose; and if the attempt were made, it is certain that the prospects for ratification would be bleak.

The United Nations Conference of 1958 considered this problem and established a Committee on Other Measures to give thought to "other possible measures for increasing the effectiveness of arbitration in settlement of private law disputes."123 The Conference and later the Economic and Social Council adopted resolutions expressing support for wider diffusion of information on arbitration laws and facilities and for greater uniformity of laws on arbitration.:24 The Conference resolution referred in that regard to the work of the Inter-American Council of Jurists, which on 
1 February 1956 recommended that the American Republics adopt a draft Uniform Law on Inter-American Commercial Arbitration, prepared by the Inter-American Juridical Committee. ${ }^{125}$ Adoption of that Uniform Law by those countries undoubtedly would do much to diminish the obstacles mentioned above. More intensive support for widespread adoption would surely be a more effective means of achieving that goal than attempting to accomplish it all through a multilateral convention. ${ }^{126}$

It is clear from the text and from the antecedents that besides promoting general acceptance of the concept of arbitration in resolving international commercial disputes, another principal aim of the Convention is to enhance the usefulness of arbitration to international business by facilitating the enforcement of final arbitral decisions in member countries other than those in which the awards are made.

B. Will the Convention facilitate enforcement in member countries of arbitral awards given in another member country?

Article 5, which is virtually identical to Article $\mathrm{V}$ of the United Nations Convention, specifies and limits the grounds upon which objections to an arbitral award given in one member country can be urged against enforcement of it in another. The recognized grounds of objection are of two types:

1. Those based on the law specified by the parties, or on the law of the place of arbitration; and

2. Those based on the law of the place of execution. Article 5 does something else: It places the burden of proving the objections on the party who urges them against enforcement; that is, it frees the claimant of the burden of proving, as a condition precedent to enforcement, that the award is free of defects.

The grounds for objection based on the law of the place of arbitration, or that specified by the parties, are limited to these:

"1. The recognition and execution of the decision (award) may be refused, at the request of the party against which it is made, only if such party is able to prove to the competent authority of the State in which recognition and execution are requested: (Emphasis added).

"a. That the parties to the agreement were subject to some incapacity under the applicable law or that the agreement is not valid 
under the law to which the parties have submitted it, or if such law is not specified, under the law of the State in which the decision was made;

"b. That the party against which the arbitral decision has been made was not duly notified of the appointment of the arbitrator or of the arbitration procedure to be followed, or was unable, for any other reason, to present his defense; or

"c. That the decision concerns a dispute not envisaged in the agreement between the parties to submit to arbitration; nevertheless, if the provisions of the decision that refer to issues submitted to arbitration can be separated from those not submitted to arbitration, the former may be recognized and executed; or

"d. That the constitution of the arbitral tribunal or the arbitration procedure has not been carried out in accordance with the terms of the agreement signed by the parties or, in the absence of such agreement, that the constitution of the arbitral tribunal or the arbitration procedure has not been carried out in accordance with the law of the State where the arbitration took place; or

"e. That the decision is not yet binding on the parties or has been annulled or suspended by a competent authority of the State in which, or according to the laws of which, the decision has been made."

It is not clear whether the matters covered by subparagraphs $b$ and $c$ may also be governed by the law of the place of enforcement. In addition, Article 5 does permit some procedural objections to be raised in the place of enforcement and it will not eliminate the impact which special remedial proceedings such as amparo in Mexico can have on arbitral awards, both domestic and foreign.

Article 5 of the Convention also specifically permits enforcement of a foreign award to be challenged on grounds related to the law of the place of enforcement. They are set forth in Section 2:

"2. The recognition and enforcement of an arbitral decision may also be refused if the competent authority of the State in which the recognition and execution is requested finds:

"a. That the subject of the dispute cannot be settled by arbitration under the law of that State; or 
"b. That the recognition or execution of the decision would be contrary to the public policy ('ordre publique') of that State."127

The United Nations Convention containing these same provisions has been in effect more than sixteen years. Its application by the courts has clearly resulted in expanding rather than diminishing the international enforceability of arbitral awards. ${ }^{28}$

A further contribution of the Convention to the enforceability of foreign awards relates to the question of reciprocity, with its attendant problems of interpretation and burden of proof. In the past, a number of countries, as a condition to enforcing foreign awards, have required a showing that the country of arbitration would enforce an award given in the enforcing country. ${ }^{129}$ The Convention will relieve claimants of this burden, as among the countries which ratify or accede to it.

On the basis of the foregoing, it is possible to state that the InterAmerican Convention can facilitate and promote enforcement, in countries which are parties, of arbitral awards given in another such country, all of which assumes and depends upon the disposition of the courts of member countries to recognize that the Convention will supersede provisions of local laws which may be inconsistent with the Convention. ${ }^{130}$

Although the Convention does not eliminate all doubts and obstacles regarding the enforcement in one member country of arbitral awards given in another, it reduces the recognized grounds of objections to the enforcement of such awards, and constitutes a significant step towards certainty and confidence in the use of arbitration in international commercial transactions.

In the growing number of states of the United States which have adopted modern arbitration laws, and under the Federal Arbitration Act, the courts of the United States have developed a policy of receptivity toward enforcement of foreign arbitral awards. ${ }^{131}$ Today, an award given abroad which meets the few required criteria will almost certainly be enforced in the United States, even if given in a country which is not a party to the U.N. Convention.

Enforcement of awards given in the United States in countries not parties to the U.N. Convention is far less certain. Apart from Ecuador, Mexico and Chile, the only treaty provisions with Latin American countries supporting such enforcement are those in modern FCN treaties, ${ }^{152}$ and Nicaragua is the only country with which an FCN treaty is in force. ${ }^{133}$ 
In Brazil ${ }^{134}$ and Colombia ${ }^{135}$ courts have enforced arbitral awards given in the United States, even in the absence of treaty provisions.

Clearly, this picture falls short of the degree of certainty and confidence which ratification by the United States and by the other American Republics of the Inter-American Convention would help to provide.

C. Would the circumstance that the United States and other countries were parties to both the Inter.American Convention and the U.N. Convention, as well as to other international agreements on arbitration, give rise to confusion, uncertainty or other problems?

Ecuador and Chile have ratified or acceded to the U.N. Convention and have signed the Inter-American Convention. Mexico has acceded to the U.N. Convention and may join the Inter-American. Both the InterAmerican (Articles 7 and 8) and the U.N. (Articles VIII and IX) Conventions are open to signature or accession by virtually all countries. Japan and several European countries, which are signatories of the U.N. Convention and have evidenced an active interest in arbitration, have extensive commercial relations with a number of Latin American countries and may decide to accede to the Inter-American Convention. It is entirely possible that a number of countries, both within and without the Western Hemisphere, may become parties to both.

In addition, the United States and a number of other countries are parties also to other multilateral or bilateral agreements relating to arbitration. Examples are the Montevideo Treaties ${ }^{136}$, the commercial (FCN) treaties of the United States ${ }^{137}$ and the European Convention on Arbitration. ${ }^{138}$

The question therefore arises whether the adoption of the InterAmerican Convention by the United States and by other countries which have adopted the U.N. Convention and/or other multilateral or bilateral agreements on arbitration would cause such confusion in the law as to make adoption of the Inter-American Convention inadvisable.

The U.N. Convention attempts in Article VII, 1, to come to grips with the problem of coordination with other bilateral or multilateral agreements:

"The provisions of the present Convention shall not affect the validity of multilateral or bilateral agreements concerning the recognition and enforcement of arbitral awards entered into by 
the Contracting States nor deprive any interested party of any right he may have to avail himself of an arbitral award in the manner and to the extent allowed by the law or the treaties of the country where such award is sought to be relied upon."

The Inter-American Convention touches the question only indirectly, in Article 4:

"* * *xecution or recognition may be ordered [or demanded] * * in accordance with the procedural laws of the country where it is to be executed and the provisions of international treaties."

Article VII, 1 of the U.N. Convention indicates that there is no bar to parties to the U.N. Convention adopting the Inter-American Convention. It is less clear, however, how Article VII, 1 would accomplish coordination of the U.N. Convention with the Inter-American Convention. Article VII, 1 would apparently preserve any right that any interested person may have to avail himself of an arbitral award under the Inter-American Convention. But Article VII, 1 does not clearly resolve the question as to whether the procedures of the United Nations Convention or the Inter-American Convention will govern.

To assess the confusion which could possibly arise from the adoption of both conventions, it is perhaps instructive to compare the treatment given by each convention to various issues which may arise during an arbitration.

1. Validity of the Arbitration Agreement. Both conventions, while using different language, uphold agreements to arbitrate future disputes and the submissions of present disputes to arbitration. The U.N. Convention in Article II, 1 states:

"Each Contracting State shall recognize an agreement in writing under which the parties undertake to submit to arbitration all or any differences which have arisen or which may arise between them ..."

The Inter-American Convention in Article 1 states:

"An agreement in which the parties undertake to submit to arbitral decision any differences that may arise or have arisen between them with respect to a commercial transaction is valid." 
While the language of the above provisions is different, the import is basically the same. The Inter-American Convention is specifically limited to commercial transactions; and the U.N. Convention, as ratified by the United States, is likewise specifically so limited.

It should be noted that the United Nations Convention (Article II, 3) puts teeth into its recognition of arbitration agreements by requiring the courts "seized of an action" covered by an arbitration agreement to refer the parties to arbitration. Presumably the Inter-American Convention, which does not contain a similar provision, would rely on local law to provide this type of relief.

Upon execution of a foreign award under the Inter-American Convention (assuming both the country of arbitration and the country of execution were parties to both Conventions) the petitioner could argue that since the Inter-American Convention provides that execution "may be ordered [or demanded] * * in accordance with the (local) procedural laws * * and the provisions of international treaties," a pending court action dealing with the same subject matter should be stayed and the for. eign arbitral award enforced, as a logical application of Article II, 3 of the U.N. Convention.

2. Procedure. Perhaps the area of greatest difference between the two conventions is the area of procedure to be followed at the arbitration. The U.N. Convention contains no provision relating to arbitration procedure. The Inter-American Convention, on the other hand, requires in Article 3 that the Rules of Procedure of the Inter-American Commercial Arbitration Commission shall govern unless the parties expressly agree otherwise. (See also, Rule 1 of the Rules of Procedure of the Inter-American Commercial Arbitration Commission which incorporates the Rules into the parties' arbitration agreement). The Rules of Procedure of the Inter-American Arbitration Commission are a detailed set of provisions similar to the Commercial Arbitration Rules of the American Arbitration Association. They provide the procedure for the initiation of arbitration, appointment of arbitrators, conduct of hearings, rendition of the award and other related matters.

It seems inevitable that the question as to which convention applies might have serious procedural consequences to the parties and, therefore, be a source of confusion and dispute.

This possibility, however, may be reduced substantially with the adoption of new arbitration rules for international trade which have been 
prepared and are under consideration by the United Nations Commission on International Trade Law (the "UNCITRAL Rules").139 The InterAmerican Commercial Arbitration Commission and other organizations have announced their intention to adopt the UNCITRAL Rules once they have been approved. ${ }^{140}$

3. Recognition of Foreign Awards. Both the U.N. Convention in Article III and the Inter-American Convention in Article 4 provide for recognition of foreign arbitral awards. While the language of those provisions differs, the intent appears to be the same. Furthermore, the grounds for refusal to recognize foreign arbitral awards set forth in Article 5 of the Inter-American Convention and in Article V of the U.N. Convention are virtually identical. There is little likelihood, therefore, that there will be confusion or conflict on this issue arising from the adoption of both conventions.

4. Summary. Although the U.N. Convention contains a provision which recognizes other multilateral and bilateral arbitration agreements, there is no clear-cut rule for coordinating that Convention with the InterAmerican Convention. The Inter-American Convention addresses the problem of coordination only indirectly. Despite this deficiency, however, there seems little likelihood of massive conflict and confusion arising from the adoption of both conventions by the same country since the conventions are largely consistent with each other, at least in terms of purpose. The area where perhaps the greatest confusion could occur is in the procedure to be followed at arbitration. This area, however, is one which is subject to the agreement of the parties. Disputes regarding procedure, therefore, could largely be avoided by the parties themselves through careful drafting of their arbitration agreements and through specification of the arbitration procedures to be followed.

Inclusion of the following sentence in the arbitration agreement or clause (when both parties are from countries which are parties to the Convention) also could help reduce uncertainty and confusion:

"The parties acknowledge that this agreement and any award rendered pursuant to it shall be governed by the 1975 Inter-American Convention on International Commercial Arbitration."

\section{Conclusions and Recommendations}

A. To a limited but important extent the Inter-American Convention promotes and gives promise of effecting modernizing changes and of ad- 
vancing uniformity in the national laws of the countries which ratify it, governing commercial arbitration.

(1) It establishes the validity of agreements to submit both future and existing commercial disputes to arbitration, facilitating the commencement of arbitral proceedings.

(2) It simplifies formal requirements for making arbitration agreements.

(3) It recognizes the right of parties to designate the law which shall govern arbitration agreements.

(4) It permits parties to designate in arbitration agreements the rules of procedure of international arbitration institutions to govern arbitral proceedings.

(5) It makes the Rules of Procedure of the Inter-American Commercial Arbitration Commission applicable to govern the conduct of all arbitral proceedings unless the parties make a different agreement, thereby promoting uniformity of arbitral procedure.

(6) It permits arbitrators to be appointed by third parties, including by arbitration institutions, and permits both nationals and foreigners to be arbitrators.

(7) It makes a final arbitral award equivalent to a judicial judgment in the place where made, enforceable in the same manner.

These changes give promise of alleviating some of the most important existing obstacles to prompt, effective commercial arbitration in the various local laws, and would constitute a major step forward.

Further progress could be made through the adoption by the several American Republics of the Draft Uniform Law of 1956, approved by the Inter-American Council of Jurists. More intensive encouragement of that action, on the part of all concerned, would be eminently worth while.

B. The lack of an effective method of resolving commercial controversies promptly and fairly is a serious burden on and deterrent to greater development of international trade in the Western Hemisphere. The Convention offers substantial progress toward filling that need, through promoting uniformity and through its underlying objective of achieving greater certainty in the enforceability of foreign arbitral awards.

1. By designating the Rules of the Inter-American Commercial Arbitration Commission to govern the conduct of all arbitration 
proceedings, unless the parties provide otherwise in their agreement, it avoids many problems which result from lack of uniformity.

2. By making a final arbitral award equivalent to a judicial judg. ment in the place where made, enforceable as such, it can expedite international enforcement in many cases.

3. It will eliminate the necessity of proving reciprocity in international enforcement of arbitral awards.

4. It reduces the number and kinds of objections which can be raised against enforcement of foreign arbitral awards, thereby reducing the availability of obstructionist measures, while preserving protection against possible unjust awards.

5. It places the burden of proving objections to the enforcement of foreign arbitral awards on the party opposing enforcement, instead of requiring the party seeking enforcement to prove validity.

The Convention, despite some ambiguities in language, constitutes a major advance in the long history of the search in the Hemisphere for a widely acceptable system of international commercial arbitration. It can enhance the climate of confidence and contribute substantially to expanded commercial relationships.

\section{APPENDIX \\ Inter-American Convention On International Commercial Arbitration}

The Governments of the Member States of the Organization of American States, desirous of concluding a convention on international commercial arbitration, have agreed as follows:

\section{Article 1}

An agreement in which the parties undertake to submit to arbitral decision any differences that may arise or have arisen between them with respect to a commercial transaction is valid. The agreement shall be set forth in an instrument signed by the parties, or in the form of an exchange of letters, telegrams, or telex communications. 


\section{Article 2}

Arbitrators shall be appointed in the manner agreed upon by the parties. Their appointment may be delegated to a third party, whether a natural or juridical person.

Arbitrators may be nationals or foreigners.

\section{Article 3}

In the absence of an express agreement between the parties, the arbitration shall be conducted in accordance with the rules of procedure of the Inter-American Commercial Arbitration Commission.

\section{Article 4}

An arbitral decision or award that is not appealable under the applicable law or procedural rules shall have the force of a final judicial judg. ment. Its execution or recognition may be ordered in the same manner as that of decisions handed down by national or foreign ordinary courts, in accordance with the procedural laws of the country where it is to be executed and the provisions of international treaties.

\section{Article 5}

1. The recognition and execution of the decision may be refused, at the request of the party against which it is made, only if such party is able to prove to the competent authority of the State in which recognition and execution are requested:

a. That the parties to the agreement were subject to some incapacity under the applicable law or that the agreement is not valid under the law to which the parties have submitted it, or, if such law is not specified, under the law of the State in which the decision was made; or

b. That the party against which the arbitral decision has been made was not duly notified of the appointment of the arbitrator or of the arbitration procedure to be followed, or was unable, for any other reason, to present his defense; or

c. That the decision concerns a dispute not envisaged in the agreement between the parties to submit to arbitration; nevertheless, if the provisions of the decision that refer to issues submitted to 
arbitration can be separated from those not submitted to arbitration, the former may be recognized and executed; or

d. That the constitution of the arbitral tribunal or the arbitration procedure has not been carried out in accordance with the terms of the agreement signed by the parties or, in the absence of such agreement, that the constitution of the arbitral tribunal or the arbitration procedure has not been carried out in accordance with the law of the State where the arbitration took place; or

e. That the decision is not yet binding on the parties or has been annulled or suspended by a competent authority of the State in which, or according to the law of which, the decision has been made.

2. The recognition and execution of an arbitral decision may also be refused if the competent authority of the State in which the recognition and execution is requested finds:

a. That the subject of the dispute cannot be settled by arbitration under the law of that State; or

b. That the recognition or execution of the decision would be contrary to the public policy ("ordre public") of that State.

\section{Article 6}

If the competent authority mentioned in Article 5.1.e has been requested to annul or suspend the arbitral decision, the authority before which such decision is invoked may, if it deems it appropriate, postpone a decision on the execution of the arbitral decision and, at the request of the party requesting execution, may also instruct the other party to provide appropriate guaranties.

\section{Article 7}

This Convention shall be open for signature by the Member States of the Organization of American States.

\section{Article 8}

This Convention is subject to ratification. The instruments of ratification shall be deposited with the General Secretariat of the Organization of American States. 


\section{Article 9}

This Convention shall remain open for accession by any other State. The instruments of accession shall be deposited with the General Secretariat of the Organization of American States.

Article 10

This Convention shall enter into force on the thirtieth day following the date of deposit of the second instrument of ratification.

For each State ratifying or acceding to the Convention after the deposit of the second instrument of ratification, the Convention shall enter into force on the thirtieth day after deposit by such State of its instrument of ratification or accession.

\section{Article 11}

If a State Party has two or more territorial units in which different systems of law apply in relation to the matters dealt with in this Conven. tion, it may, at the time of signature, ratification or accession, declare that this Convention shall extend to all its territorial units or only to one or more of them.

Such declaration may be modified by subsequent declarations, which shall expressly indicate the territorial unit or units to which the Convention applies. Such subsequent declarations shall be transmitted to the General Secretariat of the Organization of American States, and shall become effective thirty days after the date of their receipt.

\section{Article 12}

This Convention shall remain in force indefinitely, but any of the States Parties may denounce it. The instrument of denunciation shall be deposited with the General Secretariat of the Organization of American States. After one year from the date of deposit of the instrument of denunciation, the Convention shall no longer be in effect for the denouncing State, but shall remain in effect for the other States Parties.

\section{Article 13}

The original instrument of this Convention, the English, French, Portuguese and Spanish texts of which are equally authentic, shall be deposited with the General Secretariat of the Organization of American 
States. The Secretariat shall notify the Member States of the Organization of American States and the States that have acceded to the Convention of the signatures, deposits of instruments of ratification, accession, and denunciation as well as of reservations, if any. It shall also transmit the declarations referred to in Article 11 of this Convention.

IN WITNESS WHEREOF the undersigned Plenipotentiaries, being duly authorized thereto by their respective Governments, have signed this Convention.

DONE AT PANAMA CITY, Republic of Panama, this thirtieth day of January one thousand nine hundred and seventy-five.

\section{NOTES}

10AS/Ser. A/20 (SEPF); 14 INr't LeG. MTs. 336 (1975). Text is attached as Appendix [hereinafter cited as the Convention].

2Brazil, Colombia, Costa Rica, Chile, Ecuador, El Salvador, Guatemala, Honduras, Nicaragua, Panama, Paraguay, Uruguay, and Venezuela. Countries which have not yet signed the Convention are Argentina, Dominican Republic, Jamaica, Mexico, Peru, Trinidad and Tobago, and the United States.

3Panama and Chile have ratified the agreement.

4Norberg, Inter-American Commercial Arbitration Revisited, 7 Law. Am. 275, 276 (1975); see Walker, United States Treaty Policy on Commercial Arbitration 1946-1957, in International Trade Aritration 49 (Domke ed. 1958); Sullivan, United States Treaty Policy on Commercial Arbitration - 1920-1946, id. at 35.

5Draft Uniform Law on Inter-American Commercial Arbitration, Resolution VIII, Final Act, [1956] Third MeEting of the Inter-American Council of Jurists 23 (CIJ-29).

6Report of the Inter-American Juridical Committee on the Draft Convention on International Commercial Arbitration, OAS/SER. 1/VI. 1, Feb. 19, 1968.

7U.N. Doc. E/CONF. 26/9: 330 U.N.T.S. No. 4739: T.I.A.S. No. 6997.

${ }^{8}$ As to Brazil, see Recent Developments in Latin American Investment Laws, 6 Int'L Lyr. 73 (1972); Chile, see Bluth, The Andean Pact and Its Member States - A Study in Certain Formal Aspects of Subregional Integration, 1975 Private Investors ABroad 425. The Supreme Court of Justice of Cooumbis said in a decision of February 27, 1973, "In general, treaties which are concluded by the President of the Republic and are approved by law of Congress are binding. *** Since the constitutional force of treaties is greater than that of laws and decrees, legislative provisions which are adopted subsequent to the act of approval may not be opposed to [them]." Cavelier, Perdomo \& Cavelier, Boletin Legal. (June 1975).

${ }^{9}$ Norberg, supra note 4 , at 281.

10Published in English and in Spanish. Available from American Arbitration Association, 140 West 51st St., New York, N.Y. 10020. National offices are in twenty three countries.

11Lliteras, The Panama Convention Strengthens Arbitration in the Americas, 3 iaCAC, Inter-American Arbitration 3 (1975). 
12Domke, International Arbitration of Commercial Disputes, 2 Institure on Private Investments Abroad 136 (1960); Goldman, Arbitration in Inter-American Trade Relations, 7 INT.-AMt. L. R. 79 (1965).

13 Goldman, $i d$. at 79.

14Decree-Law No. 735, Oct. 23, 1963, Reg. Of. No. 90, at 741 (Quito 1963).

15 Goldman, supra note 12 , at 80 .

16Commercial. Code, art. 1 at 180 (effective April 2, 1973).

17Goldman, El Arbitraje Comercial en las Americas, 1969 Tecnicas Financieras 505 (Mexico, May.June and July-August 1969); Domke, supra note 12, at 136.

18Goldman, id. at 506-07.

${ }^{19}$ Argentina, Bolivia, Costa Rica, Guatemala, Nicaragua, Panama, Peru, and Uruguay.

20Brazil. Decision of the First Chamber, Court of Appeals of the Federal District, April 23, 1952, Gac. Of. of Aug. 25, 1955, at 2945.

21Mexico. C. CIV. PRO. FED. DIST., arts. 220-23.

${ }^{22}$ Goldman, supra note 17 , at 508 .

23E.g., C. CIV. PRO., art. 504 (Venezuela); Lliteras, Ex Parte International Commercial Arbitration, Ms., Oct. 1, 1975, at 3; Goldman, id. at 507.

24 Lliteras, supra note 23 , sets forth excerpts of the several statutes in an appendix.

25Lliteras, supra note 23 , at 2.

26E.g., Guatemala, Mexico; see Goldman, supra note 17, at 512.

27Brazil, Colombia, Costa Rica, Cuba, Ecuador (Law 735), Honduras, Paraguay, and Venezuela. Goldman, supra note 17, at 513; Abbott, Latin America and Inter. national Arbitration Conventions, 17 HARv. INT'L. L.J. 132 (1976).

28Briseno, Convencion Interamericna sobre Arbitraje Comercial Interamericano, Ms. Sep. 1975, at 5; Goldman, supra note 12, at 82.

${ }^{29}$ Argentina on May 3, 1976 amended Article 1 of the Code of Civil and Commercial Procedure to revoke, under most conditions, the prior prohibition against agreements submitting controversies relating to property matters ("asuntos patrimoni. ales") to foreign courts and to arbitral tribunals which act outside Argentina. LA NACion (B. Aires), May 4, 1976, at 1. Bolivia requires that arbitrators be lawyers except when the arbitration concerns strictly technical matters. Commercial Code, art. $I$ at 186. But parties may provide otherwise in their agreement. $I d$. at 180 .

${ }^{30}$ Goldman, supra note 17 , at 669.73 ; Briseno, supra note 28 , at 3 ; Abbott, supra note 27 , at 132 .

31 E.g., Brazil, C.C.P. arts. 1, at 1,096-97 (1973); Mexico, Goldman, supra note 17 , at 674 .

32Briseno, supra note 28, at 3; Goldman, supra note 17, at 672; Folsom, Investing in Mexico, 1974 Private Investors Abroad 137; Letter of T.J. Skola (March 30, 1976). See also Briseno, El Arbitraje en el Derecho Privado 273.95 (Mexico 1963); Alcala-Zamora y Castillo, La ejecion de las sentencias arbitrales en Mexico, Communciones Mexicanas al $V$ Congreso Intennacional de Derecho Comparado 45-64 (Mexico 1958); Toral Moreno, El Arbitraje y el juicio de Amparo, 37 Jur. $601-31$ (Mexico 1957); Liceaga y Aguiar, El juicio de amparo y el laudo arbitral, 4 EL Foro 145.59 (Mexico 1955). The amparo procedure is equally available to the losing party from a final decision in a court action. 
${ }^{33}$ Domke, supra note 12, at 155; Goldman, supra note 12, at 82-83; Abbott, supra note 27, at 133 (citing statutory provisions).

34Goldman, supra note 12, at 82; Abbott, supra note 27, at 134 (citing statutes) ; Mihm, International Commercial Arbitration in Latin America, 15 ARB. J. 17, 21 (1960).

${ }^{35}$ Abbott, supra note 27, at 134; see Cardenas, Metodos de solucion de con. troversias comerciales internacionales, 8 DERECHO DE LA INTECRACION 92 (B. Aires Nov. 1975).

36 Goldman, supra note 12 , at 81 .

37Nadelman, Uniform Legislation vs. International Conventions, in INTERNATIONAL Trade Arbitration 170 (Domke ed. 1958).

38Text in Vita, Comparative Study of American Legislation Governing Commercial. Arbitration (Inter-American High Commission, U.S. Section) 59 (1928); Eder, American-Colombian Private International Law, Parker School of Foreign and Comparative Law, Bilateral Studies, No. 5 (1956); Goldman, supra note 12, at 83; Cardenas, supra note 35, at 92.

39Fenwick, Inter-American Commercial Arbitration, in International Trade Arbitration 181 (Domke ed. 1958).

40Decree No. 21,887, of March 22, 1932; Goldman, supra note 12, at 84.

41Texts in International. Trade Arbitration 283, 285 (Domke ed. 1958); see Contini, International Commercial Arbitration, 8 Am. J. Comp. L. 287-89 (1959) ; Sultan, The United Nations Arbitration Convention and United States Policy, 53 AM. J. INT'L. L. 809-11 (1959); Nadelman, supra note 37, at 170-71.

42Code of Private Intrenational Law, signed at Havana on Feb. 20, 1938, 86 L.N.T.S. III; Goldman, supra note 12, at 83 ; Nadelman, supra note 37 , at 171; Norberg; supra note 4, at 283; Caicedo Castillo, Estudio Comparativo del Cordigo de Bustamante, los Tratados de Montevideo y el Restatement of the Law of Conflict of Laws (Pan American Union, Washington, D.C., March, 1954).

43Resolution XLI, VII International Conference of American States (Montevideo Dec. 23, 1933); Goldman, supra note 12, at 74; Fenwick, supra note 39, at 181; Norberg, supra note 4 , at 279.

44Goldman, supra note 12, at 80; Fenwick, supra note 39, at 182; Domke, supra note 12 , at 137 .

45Law No. 2 February 25, 1938, 74 D.0. 23,732, at 68 (March 12, 1938); see Goldman, supra note 12, at 80; Domke, supra note 12, at 137; Fenwick, supra note 39 , at 183 .

46Decree No. 1400 of Aug. 11, 1973, as amended by Decree No. 2019 of Oct. 26, 1970 (Arts. 663-77).

${ }^{47 C . C . P ., ~ D e c r e e-L a w ~ N o . ~} 1608$ of Sep. 18, 1939; see Goldman, supra note 12, at 80 ; Domke, supra note 12 , at 137 .

48Law No. 5,869, of Jan. 11, 1973 (Arts. 1,070-102).

49Decree-Law No. 735, Oct. 23, 1963, Reg. Of. No. 90 at 714 (Quito 1963); see Abhott, supra note 27, at 132; Goldman, supra note 12, at 80.

50Argentina, Bolivia, Brazil, Colombia, Paraguay, Peru, and Uruguay. Goldman, supra note 12 , at 80 .

51 Text in 2 Recister of Texts of Conventions and Other Instruments Concerning International Trade Law 21 (United Nations 1973). 
52Abbott, supra note 27, at 133-34; Cardenas, supra note 35, at 92; Goldman, supra note 12, at 84 ; Nadelman, supra note 37 , at 170 .

53 Fenwick, supra note 39 , at $182-83$. at 280 .

54Note 5 supra; see Goldman, supra note 12, at 76,80; Norberg, supra note 4,

${ }^{5}$ See text accompanying note 49 , supra.

56 Abbott, supra note 27, at 135, n. 31; Goldman, supra note 12, at 81.

57Sultan, supra note 41 , at 811-13.

58Contini, supra note 41, at 290-91; Sultan, supra note 41, at 813-15.

${ }^{59}$ Note 7 supra; see Domke, The United Nations Conference on International Commercial Arbitration, 53 AM. J. INT'L L. 415 (1959).

${ }^{60}$ Contini, supra note 41 , at 291.

${ }^{61}$ Ecuador ratified in 1962 and Trinidad and Tobago acceded in 1966; Mexico acceded in 1971, Cuba in 1974 and Chile in 1975. See Abbott, supra note 27, at 135; Aksen, A Practical Guide to International Arbitration, 1975 Private INvestors Abroad 80-81.

62Miller, Protection of Private Foreign Investment by Multinational Convention, 53 Ам. J. INT'L L. 371 (1959).

${ }^{63}$ Text in 2 INT'L LyR. 331 (1968); Brower, The Future for Foreign Investment Recent Developments in the International Law of Expropriation and Compensation, 1975 Private Investors Abroad 93,99.

64T.I.A.S. No. 6090, 575 U.N.T.S. 159, 17 U.S.T. 1270; Text at 4 INT'L LEG. Mrs. 532 (1965).

${ }^{65}$ McCrate, International Arbitration in a New Climate of Foreign Investment, 1975 Private Investons ABroad 1; Schmidt, Arbitration Under the Auspices of the International Centre for Settlement of Investment Disputes (ICSID), 17 HaRv. INT'L L. J. 90 (1976).

${ }^{66}$ Association of the Bar of the City of New York, Committee on Inter-American Affairs, The U.N. Charter of Economic Rights and Duties of States, 30 The Recond 411 (1975); MeCrate, supra note 65, at 22; see Chiriboga, International Arbitration, 4 INT'L LYR. 804 (1970); Stebbings, La Ley argentina sobre inversiones extranjeras y su inspiracion en el Mercado Comun Andino, 8 Derecho de Integracion 193 (B. Aires March, July 1975); cf. Abbott, supra note 27, at 137-39.

67 Aksen, supra note 61, at $87-89$.

68Translation in 11 Int'L Leg. Mats. 126 (1972). Pursuant to the provisions of Decision 24 (Article A, Transitory) each of the member countries specifically incorporated the provisions of the Decision into national law: Chile, Decree No. 482, D.O., June 30, 1971; Bolivia, Decree Law 9789, of June 31, 1971; Peru, Law 18900 of 1971; Ecuador, Decree No. 794, June 30, 1971; Reg. Of. July 12, 1971; Colombia, Law 8 of 1973 and Decree 1900 of 1973 ; and Venezuela, Decree Nos. 62 and 63 of April 28, 1974 (Trans. in INT'L Leg. MTs. 1200 et seq., 1974).

69Law on Foreign Investments No. 20,557, of Nov. 29, 1973 (Art. 6b). Translation in 12 INT'L LEG. Mrs. 1489 (1973); see Cardenas, supra note 25, at 97.

70Lopez Valdez, The Andean Foreign Investment Code: An Analysis, 7 J. Iw T'L L. \& Ec. 15 (1972); Stebbings, supra note 66, at 193.

71See Oliver, The Andean Foreign Investment Code: A New Phase in the Quest for Normative Order as to Direct Foreign Investment, 66 AM. J. INT'L LAw 
773 (1972) ; cf. Abbott, supra note 27, at 137; Lliteras, supra note 11, at 4, who suggests that the problem of Art. 51 would be "resolved" if the Andean Group countries ratify the Inter-American Convention. This seems unlikely, since these countries appear to view Article 51 as involving their public policies.

72Report of the Inter-American Juridical Committee on the Draft Convention on International Commercial Arbitration, OAS/SER. I.VI.1, Feb. 19, 1968; see Abbott, supra note 27, at 136; Norberg, supra note 4, at 280.

${ }^{73}$ Norberg, supra note 4 , at $280,281$.

74Resolution 11, Resolutions, Recommendations and Declarations, XIX Conference 8 (Washington, D.C. 1975).

75Sulljvan, supra note 4 , at 35 , passim.

76United States Asphalt Refining Co. v. Trinidad Lake Petroleum Co., 222 F. 1006 (D.S.D.N.Y. 1915); see Contini, supra note 41, at 285.

77N.Y. Sess. Laws, C. 275 (several times amended, now N.Y. Crv. Prac. Law \& R. $\$ \$ 7501-14)$.

78For a current list see The Lawyer and Arbitration, The American Arbitration Association.

${ }^{79}$ Act of Feb. 12, 1925, 43 Stat. 883 (now 9 U.S.C.).

80Sullivan, supra note 4, at 38; see Goldman, supra note 12 , at 91.

81 Sullivan, supra note 4 , at 40.

82Sullivan, supra note 4 , at $40-42$.

83 Note 42 supra, and accompanying text.

84 Notes 38 \& 51 supra.

85Sullivan, supra note 4, at 42-43; see Sultan, supra note 41, at 818-19.

${ }^{86}$ Aksen, supra note 67, at 59; Domke, supra note 12, at 153; Sultan, supra note 41, at 817; accord Sargant v. Monroe, 268 App. Div. 123, 49 N.Y.S.2d 273 (1944), affd 7 App. Div. 2d 977, 49 N.Y.S.2d 546 (1944). See also Mittelman v. Spies, 129 N.Y.S.2d 822 (1954) and Farr v. CIA, 243 F.2d 342 (1957).

87Oilcakes and Oilseeds Trading Co. v. Sinason Teicher Inter-American Grain Corp., 9 Misc. 2d 651, 183 N.Y.S.2d 378 (1958), aff'd 7 App. Div. 2d 977, 183 N.Y.S.2d 83 (1959), affd 8 N.Y.2d 852 (1960); see Domke, supra note 12, at 153.

88Standard Magnesium Corp. v. Otto Fuchs, K.G. Metallwerke, 251 F.2d 455 (10th Cir. 1957); Domke, supra note 12, at 154.

${ }^{89}$ Rosenthal, Arbitration in the Settlement of International Trade Disputes, 11 Law \& Contemp. Prob. 810 (1945-46), quoted in Sultan, supra note 41, at 818.

90Restatement (Second) of Conflict of Laws (Tent. Draft No. 5,1960 ).

91Sultan, supra note 41 , at 818.

92Sullivan supra note 4 , at 44 n.32.

${ }^{93}$ Note 43 supra, and accompanying text; Norberg, supra note 4, at 279.

94Note 43 supra.

95Sullivan, supra note 4 , at 43. 1299.

96Treaty of Friendship, Commerce and Navigation, Nov. 4, 1946, pt. 2, 63 Stat. 
975ultan, supra note 41, at 820-21; Aksen, supra note 67, at 58, 82; Walker, supra note 4 , at 49. (1951).

98S. Exec. H, 84th Cong., 1st Sess (1955) ; S. Exec. M, 82d Cong., 1st Sess.

99Note 98 supra.

100Jan. 21, 1956, 8 U.S.T. 2043, T.I.A.S. 3942, 285 U.N.T.S. 231.

101 Aksen, supra note 61, at 182.

102Domke, supra note 12, at 155.

${ }^{103}$ Text accompanying note 81 supra.

104 Handbook of the National Conference of Commissioners on UniForm State LAWS 287 (1958).

105 Note 78 supra.

${ }^{106}$ Contini, supra note 41, at 291; Domke, supra note 59, at 415.

107 Note 59 supra.

${ }^{108}$ Contini, supra note 41 , at 291.

109The arguments against United States participation are summarized in Sultan, supra note 41, at 817.20; see Fellers, Arbitral Resolution of International Disputes, 1974 Private Investors Abroad 345-46; Goldman, supra note 12, at 86.

noabA Int'l and Comp. Law Section 194 (1960); Hynning \& Haight, Inter. national Commercial Arbitration, 48 A.B.A.J. 236 (1962); Quigley, Accession by the United States to the United Nations Convention on the Recognition and Enforcement of Foreign Judgments, 70 YALE L. J. 1049 (1961); Sultan, supra note 41, at 818-20.

111 Note 64 supra and accompanying text.

112Schmidt, supra note 65; McCrate, supra note 65.

113114 Cong. Rec. 29605 (1968).

114Pub. L. No. 89-25, 84 Stat. 692 (codified in 9 U.S.C. $\& \$ 201$ et seq.).

115T.I.A.S. No. 6997, 330 U.N.T.S. 38.

1169 U.S.C. \$ \& 202-203; see Quigley, Convention of Foreign Arbitral Awards, 58 A.B.A.J. 824 (1972).

${ }^{117}$ Aksen, American Arbitration Accession Arrives in the Age of Aquarius, 3 Sw. U.L.R.I. (1971).

118417 U.S. 506 (1974).

${ }_{119}$ Parsons and Whittemore Overseas Co. v. Societe Generale de l'Industrie du Papier (RAIKA), 508 F.2d 969 (2d Cir. 1974); Fotochrome Inc. v. Copal Co., 377 F.Supp. 26, affd 517 F.2d 512 (2d Cir. 1975); Island Territory of Curacao v. Solitron Devices, Inc., 489 F.2d 1313 (2d Cir. 1973); McCreary Tire and Rubber Co. v. CEAT, S.P.A., 501 F.2d 1032 (3d Cir. 1974); Splosna Plovba of Piran v. Agrelak Steamship Corp., 381 F.Supp. 1368 (S.D.N.Y. 1974); I/S Starborg v. National Metal Convertors, Inc., 500 F.2d 424 (2d Cir. 1974); Hidrocarburos y Derivados, C.A. v. Nereus Shipping, S.A. 75 Civ, 464 (S.D.N.Y. 1975); see Aksen, supra note 61 , at $72-78$.

${ }^{120} \mathrm{~A}$ comprehensive comparative analysis of the domestic laws on arbitration of the Latin American countries and the United States, detailing the various requirements as of 1969, is given in Goldman, El Arbitraje Comercial en las Americas, supra note 17. Since that time, Brazil has adopted a new Code of Civil Procedure, 
Law No. 5.869 of Jan. 11, 1973, which deals with arbitration at arts. 1.072-102, as has Colombia, Decree No. 1400, Aug. 6, 1970, modified by Decree No. 2019; Oct. 26, 1970, both effective Jan. 1, 1971. Articles $663-77$ on arbitration and $379-86$ on appeals (revisiones) represent a considerable regression from Colombia's earlier Law No. 2, Feb. 25, 1938. Bolivia has adopted a new Commercial Code, Apr. 2, 1973, Arts. 1179-94 of which deal with arbitration and incorporate a number of modern concepts.

121 Goldman, supra note 12 , at 70-71.

122 Fellers, supra note 109 , at 344.

${ }^{123}$ Contini, supra note 41 , at 287 ; Domke, supra note 59 , at 415 .

124 United Nations Conference on International Commercial Arbitration, Final Act, U.N. Publ. Sales No. 58.V.6; and Economic and Social Council Resolution 708 (XXVII).

125 Note 54 supra and accompanying text.

126 Nadelman, supra note 37, at 177; Goldman, supra note 12, at 80,81 . Another example of an action taken pursuant to the U.N. Resolution of Other Measures to advance the effectiveness of arbitrations the European Convention on International Commercial Arbitration, Apr. 21, 1961, 2 ReG. of Texts of Conventions and Other Instruments Concerning International Trade Law 34 (United Nations).

127In some countries, disputes arising out of agreements in which governments or government-owned companies are parties cannot be submitted to arbitration outside the country, as a matter of constitutional law rule. Vanossi, opinion, Dec. 10, 1973. Compare Norberg, supra note 4, at 159-64. While the language of the Convention is broad enough to include such agreements within its provisions, the extent to which it would apply to them in practice is not now clear.

128Aksen, supra note 61, at 72-78; supra note 119.

${ }^{129} \mathrm{Goldman}$, supra, note 17 , at 675 .

130 See note 11 supra.

131Notes 82-89 \& 119 supra and accompanying texts.

132 Domke, supra note 12 , at 155 .

133 Aksen, supra note 61 , at $82-83$.

134M. Argueso \& Co. v. Aparicio, F. Sup. Ct., Foreign Judgment No. 1556, decisions of Aug. 4, 1958 and May 4, 1959 (unreported), apud Domke, supra note 12 , at 159.

135Revlon Prod. Corp. v. Salcedo Hermanos y CIA., Sup. Ct. Of Justice (1952), roted in Goldman, supra note 12, at 83; Hide Trading Corp. v. Field Echenique Cia., Sup. Ct. of Justice, Oct. 26, 1951, trans. 6 ARs.J. (n.s.) 159 (1951), noted in Goldman, supra note 12, at 83; Domke, supra note 12, at 158.

136 Notes 38 \& 51 supra, and accompanying text.

137Notes 95-102 supra, and accompanying text.

138European Convention on International Commercial Arbitration, Apr. 21, 1961, supra note 26.

${ }^{139}$ United Nations Commission on International Trade Law, Revised draft set of arbitration rules for optional use in ad hoc arbitration relating to international trade, A/CN.9/112, Nov. 7, 1975.

140 Norberg, supra note 4, at 277; Aksen, supra note 61. 